Reprod. Nutr. Dévelop., 1985, 25 (4 A), 629-640.

\title{
The effect of sudden solar exposure on thermophysiological parameters and on plasma prolactin and cortisol concentrations in male Creole goats
}

\author{
D. SERGENT, P. BERBIGIER, G. KANN $(*)$, J. FEVRE (*)
}

Unité de Bioclimatologie animale et Station de Recherches zootechniques, I.N.R.A. 97170 Petit-Bourg, Guadeloupe (F.W.I.)

(*) Laboratoire de Physiologie de la Lactation, I.N.R.A. 78350 Jouy-en-Josas, France.

Summary. Rectal temperature (RT), respiratory rhythm (RR), plasma cortisol and prolactin (PRL) levels and haematocrit were measured at noon in male Creole goats during their habituation to shade, during sudden exposure to sunlight and then while they were kept outdoors. Data on the microclimatic environment, especially black-globe temperature ( $\mathrm{Tg}$ ), were recorded.

On the day (DO) the bucks were put in the sun, the increase of RT and RR, characteristic of circadian rhythm, was amplified (RT : $40.84 \pm 0,23{ }^{\circ} \mathrm{C}$ vs $39.48 \pm 0.19{ }^{\circ} \mathrm{C}$ $\mathrm{P}<0.001 ; \mathrm{RR}: 98 \pm 22$ vs $35 \pm 3$ respirations/min ; $\mathrm{P}<0.01$ ). Plasma cortisol also increased (17.7 \pm 8.6 vs $5.57 \pm 1.7 \mathrm{ng} / \mathrm{ml} ; \mathrm{P}<0.05)$. After $24 \mathrm{~h}$ (D1), plasma prolactin concentration increased dramatically $(923 \pm 653$ vs $90 \pm 22 \mathrm{ng} / \mathrm{ml} ; \mathrm{P}<0.05)$ and haematocrit decreased $(28.6 \pm 2.3$ vs $33 \pm 2.3 \% ; \mathrm{P}<0.05)$.

To clarify the simultaneous effects of time $(t)$ and $\mathrm{Tg}$, we developed a model Lognormal on $t$ and linear on Tg for RR and PRL. A model decreasing exponentially with $t$ and linear with $\mathrm{Tg}$ was developed for $\mathrm{RT}$; the determination coefficients were $\mathrm{R}^{2}=0.96,0.75$ and 0.59 , respectively.

About 3 weeks later, after the adaptation period, RT, RR and plasma PRL stabilized ; RT and RR returned to shade values while the PRL level remained higher than the shade PRL level $(248 \pm 109$ vs $130 \pm 50 \mathrm{ng} / \mathrm{ml} ; \mathrm{P}<0.05)$

The 24-hour time-lag in prolactin hypersecretion and the role of prolactin in thermoregulation are discussed.

\section{Introduction.}

Ruminants subjected to heat develop thermolytic mechanisms, such as panting and sweating (Bianca, 1965), and voluntarily restrict their food intake. However, these mechanisms are not fully efficient immediately and a period of adaptation to the new environment is necessary (Ladell, 1964). 
The aim of the present experiment was to define the parameters involved in physiological response to heat constraint and to study the adaptation period using such simple thermophysiological criteria as rectal temperature, respiratory and cardiac rhythms and hormonal (prolactinemia and cortisolemia) and blood (haematocrit and serum electrolyte concentration) factors.

Shade-acclimatized male Creole goats were suddenly exposed to the sun in a natural tropical environment that also included nocturnal cooling (natural photoperiod : 12 to $13 \mathrm{~h}$ of light). This paper describes the physiological events occurring when the bucks were abruptly submitted to direct sunlight. We were particularly interested in the time required to develop a heat-loss mechanism and the time-lag in prolactin hypersecretion.

\section{Material and methods.}

The experiment was carried out at the I.N.R.A. farm "Gardel in GrandeTerre $"$ on a dry plateau in Guadeloupe, French West Indies $\left(16^{\circ} \mathrm{N}\right.$ latitude and $61^{\circ} \mathrm{W}$ longitude).

Animals and feeding. - Four entire dwarf male goats with a mean age of $390 \pm 9$ days and a mean live weight of $16.75 \pm 0.86 \mathrm{~kg}$ (mean \pm SD) were kept tethered in cages similar to metabolism crates under a metal shelter from September 1982 to April 1983. On April 15, 1983 they were suddenly put outside in their cages and remained there until June 20, the dry season.

They were fed pangola (Digitaria decumbens) ad libitum; the pangola was cut at 33 days (mean age of regrowth) and included about $23 \%$ dry matter without concentrate supplement. Water was available ad libitum.

Measurement frequency. - Four days before solar exposure, bioclimatic and physiological measurements were taken every day between 11.00 and 12.30 . The first day of exposure, they were taken every hour from 8.00 and every 20 min between 11.00 and 12.00 noon.

At 12.00 when the animals were still under the shelter, hormones, but not respiratory rhythm (RR), rectal temperature (RT) or black-globe temperature $(\mathrm{Tg})$, were measured because of the lack of time; the goats were put in the sun between 12.00 noon and 12.10. These measurements were continued every $10 \mathrm{~min}$ until 13.00 and then every hour until 17.00. However, cardiac rhythm and haematocrit were not measured every time. Serum electrolytes were measured only during the hour the animals were actually in the sun.

Every day on the following days, the measurements were carried out between 11.00 and 12.00 and then at wider intervals. The experimental period extended from D-4 (four days before solar exposure) to D66 (last measurement).

Climatic measurements. - Dry (Td) and wet (Tw) air temperatures were measured using an Assman psychrometer placed at the height of the animals. Air velocity (V) was recorded with two cup anemometers (one inside the shelter and the other outside) having a starting threshold of $0.8 \mathrm{~m} / \mathrm{sec}$.

Black-globe temperature $(\mathrm{Tg})$ was measured with an empty copper sphere painted black and containing a bulb thermometer at its center. This black-globe 
temperature is a good index of the heat load (temperature and radiation) actually felt by a non-sweating animal (Berbigier, 1982 ; Chemineau and Ravault, 1984).

Thermophysiological measurements and blood sampling. - The physiological parameters were measured simultaneously as follows :

- rectal temperature (RT) by a medical thermometer left for $1 \mathrm{~min}$ in the rectum :

- respiratory rhythm (RR) by counting the flank beats ;

- cardiac rhythm (CR) by a stethoscope.

At the same time, blood samples were taken from the jugular vein with EDTA/Na vacutainers for plasma hormone assay; silicon tubes were used for serum electrolyte determination. Blood samples were immediately put at $4^{\circ} \mathrm{C}$, then centrifuged for $10 \mathrm{~min}$ at $5000 \mathrm{rpm}$. The plasma was collected and deepfrozen $\left(-15^{\circ} \mathrm{C}\right)$ until assay.

A sample of the total blood was put into capillar tubes for haematocrit determination (centrifugation at $10000 \mathrm{rpm}$ for $4 \mathrm{~min}$ ).

Hormone assay and ionic concentration. - Cortisol was quantified according to the competitive protein binding radioassay of Murphy (1967) modified by Bosc and Fevre (1977) using dog CBG. Intra-assay variability averaged $10 \%$. Prolactin (PRL) was measured according to the radioimmunoassay of Kann (1971); assay sensitivity was $0.3 \mathrm{ng} / \mathrm{ml}$. The results are expressed in $\mathrm{ng}$ of PRL PS $7 \mathrm{NIH} / \mathrm{ml}$ of plasma. Intra and inter-assay variation coefficients were 5.3 and $8.4 \%$, respectively. Electrolyte (sodium and potassium) concentrations in the serum were determined using an emission spectrometer (Guéguen, Nutrition, Jouy-en-Josas).

Statistical analysis. - The mean was always expressed with the standard deviation $(M \pm S D)$. The paired $t$-test was used to compare mean sun values with mean shade values. The correlation coefficient (simple linear regression) was tested by the t-test.

Mathematical models. - Black globe temperature and time had the strongest effects on RR, PRL and RT ; in order to better quantify these effects, mathematical models were used on the three variables. These models are only descriptive, not explicative.

- At a given time, RR, PRL and RT depended linearly on Tg.

- At a given $\mathrm{Tg}, \mathrm{RR}$ and PRL reached a maximum then tended towards a limit value when $t \rightarrow \infty$. Maximal RT was reached as soon as $t=0$.

A model, Log-normal (i.e. involving a Gaussian function of the Neper-log of time) on time and linear on $\mathrm{Tg}$, was developed to show the simultaneous effects of these parameters on RR and PRL. For RT, which almost reached its absolute maximum immediately upon solar exposure, we used a model that decreased exponentially with time and was linear with $\mathrm{Tg}$. The model parameters were adjusted to the experimental data using the least-squares method (Bachacou et al., 1981).

- The general equation of the model for $R R$ and PRL was : $(X-A)=b(T g-(A+c) / b) \cdot\left(1+B \exp \left(-(\operatorname{Lnt}-C)^{2} / D\right)\right)$ where $t$ is time in days and $\mathrm{Tg}$ the black-globe temperature in ${ }^{\circ} \mathrm{C} ; \mathrm{A}, \mathrm{B}, \mathrm{C}, \mathrm{D}, \mathrm{b}$ and $\mathrm{c}$ are parameters. 
The zero on the time coordinate corresponds to the instant that solar exposure began. The time-dependent term of the right-hand side of the equation tends to 1 when $t$ tends towards the positive infinite. The $X$ value tends towards $X=b$ $\mathrm{Tg}-\mathrm{c}$. To avoid adjusting too many parameters by the least-squares method, $b$ and $\mathrm{c}$ were determined by the linear regression on $\mathrm{Tg}$ of data observed after stabilization.

This model allowed us to estimate :

- the time at which the maximum of $X$, at a given $T g\left(t_{\max }=\exp (C)\right)$, was reached ;

- the time of return to equilibrium (i.e. relaxation time, arbitrarily defined as the time after which $\left.\left(X-X_{\infty}\right) /\left(X_{\max }-X_{\infty}\right) \leqslant 0.05\right)$. This condition in the log-normal model amounted to $\exp \left(-\left(\operatorname{Lnt}-C^{2} / D\right) \leqslant 0.05\right.$ and in the exponential model to $\exp (-t / C) \leqslant 0.05$;

- The RT model was :

$(X-A)=b(T g-(A+c) / b) \cdot(1+B \exp (-t / C)) ;$

$\mathrm{b}$ and $\mathrm{c}$ were determined as above. In this model relaxation time was exp $(-t / c) \leq 0.05$.

\section{Results.}

1) Mean microclimatic conditions. - During the experiment the mean values of maximal and minimal temperatures, maximal and minimal relative humidity, mean daily global radiation and air velocity (measured at a meteorological station near the experimental site) were $29.05 \pm 0.77{ }^{\circ} \mathrm{C}, 24.39 \pm 1.39{ }^{\circ} \mathrm{C}, 100 \%$, $78.74 \pm 5.78 \%, 18.89 \pm 4.99 \mathrm{MJ} / \mathrm{m}^{2} /$ day and $3.06 \pm 0.71 \mathrm{~m} / \mathrm{sec}$, respectively. Mean rainfall during this period was $3.86 \pm 7.3 \mathrm{~mm} /$ day. However, black-globe temperature was the main bioclimatic reference.

2) Physiological parameters in shade. - From $D-4$ up to and including the morning of DO, the mean values of the thermophysiological and endocrine parameters measured between 11.00 and 12.00 were: RR : $35 \pm 3$ inspirations/min ; RT : $39 \pm 0.27{ }^{\circ} \mathrm{C} ; \mathrm{CR}: 81 \pm 3$ heartbeats $/ \mathrm{min}$; haematocrit : $33 \pm 2.3 \%$; plasma cortisol : $4.5 \pm 0.83 \mathrm{ng} / \mathrm{ml}$; plasma prolactin : $130 \pm 50 \mathrm{ng} / \mathrm{ml}$.

3) Immediate physiological reactions. - Figure 1 (DO) shows the thermophysiological and hormonal data in relation to $\mathrm{Tg}$; in passing from shade to direct sunlight, the animals had a heat overload $\left(\mathrm{Tg}\right.$ increase of $7.8^{\circ} \mathrm{C}, 29.57$ to 37.37) inducing an increase in the RT of $1.32^{\circ} \mathrm{C} . \mathrm{h}^{-1}$ between 11.40 and 12.40 .

A simultaneous increase in RT $\left(40.84 \pm 0.23\right.$ at 13.00 vs $39.48 \pm 0.19^{\circ} \mathrm{C}$ at $11.40 ; P<0.001), R R(98 \pm 22$ at 13.00 vs $35 \pm 3 \mathrm{insp} / \mathrm{min}$ at 11.40 ; $P<0.01)$ and cortisol $(17.7 \pm 8.61$ at 12.10 vs $5.57 \pm 1.67 \mathrm{ng} / \mathrm{ml}$ at 12.00 ; $P<0.05)$ was observed.

Before solar exposure, RT and RR began to increase due to circadian rhythm; this point will be discussed later. 


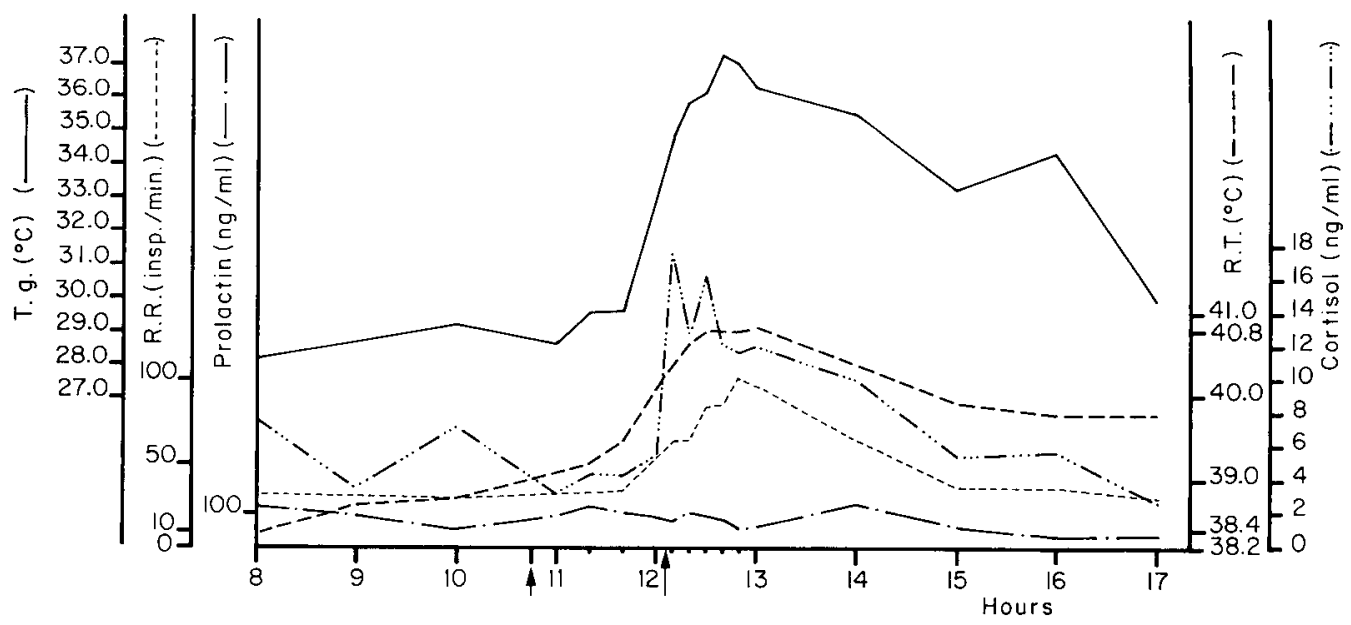

FIG. 1. - Profiles of thermophysiological (RR, RT) and hormonal (cortisol, prolactin) parameters on $D O$ before and after solar exposure at 12.00 noon compared with variations in black-globe temperature $(\mathrm{Tg})$. Each point is the mean of $n=4$ bucks and of $\mathrm{Tg}$ which was recorded when each animal was measured. The small arrow indicates when forage was distributed and the big arrow designates the beginning of solar exposure.

There was no significant increase in PRL, and CR increased non-significantly from $85 \pm 9$ to $120 \pm 20$ heartbeats $/ \mathrm{min}$. Serum potassium rate tended to decrease one hour after insolation $(256 \pm 6$ vs $223 \pm 13 \mathrm{mg} / \mathrm{l} ; P<0.02)$, whereas sodium rate $(3.13 \pm 0.07 \mathrm{~g} / \mathrm{l})$ remained steady; between 1 and 5 hours after insolation, the haematocrit did not change significantly.

4) Mean and long-term physiological reactions. - Figure 2 shows the variation of the thermophysiological (RR and RT) and endocrine (prolactin) parameters compared to that of Tg from D-4 to D49. Generally speaking, PRL an RR varied according to $\mathrm{Tg}$. On D1, PRL increase was significant $(923 \pm 653$ vs $90 \pm 22 \mathrm{ng} / \mathrm{ml} ; \quad P<0.05$ ) (the first large standard deviation, due to high variability between animals, ranged from 369 to $1832 \mathrm{ng} / \mathrm{ml}$. From D1 to D45, the correlation coefficient between RT and PRL was $r=0.64(P<0.01)$ when globe temperature was higher than the threshold of $32{ }^{\circ} \mathrm{C}$.

An absolute PRL maximum (1 $035 \pm 279 \mathrm{ng} / \mathrm{ml})$ was obtained at D9 which then decreased to a steady level after about 20 days. At this time (i.e. from D20), the circulating PRL rate was significantly higher in the sun than in the shade $(248 \pm 109$ vs $130 \pm 50 \mathrm{ng} / \mathrm{ml} ; P<0.05)$. This confirms our previous results which showed a higher prolactinemia in bucks kept outdoors permanently in the sun and fed a concentrate-poor diet than in those kept in a shelter and fed the same diet (Sergent et al., 1984). The PRL increase between D45 and D49 was not significant.

An absolute RR maximum was observed at D3 ( $266 \pm 38$ inspirations $/ \mathrm{min}$ ) which then decreased and stabilized at D15 (42 \pm 4 not significantly different from $35 \pm 3$ inspirations/min for shaded animals), while RT returned to equilibrium at D24 (39.51 \pm 0.32 not significantly different from shaded RT: $\left.39.48 \pm 0.19^{\circ} \mathrm{C}\right)$. 


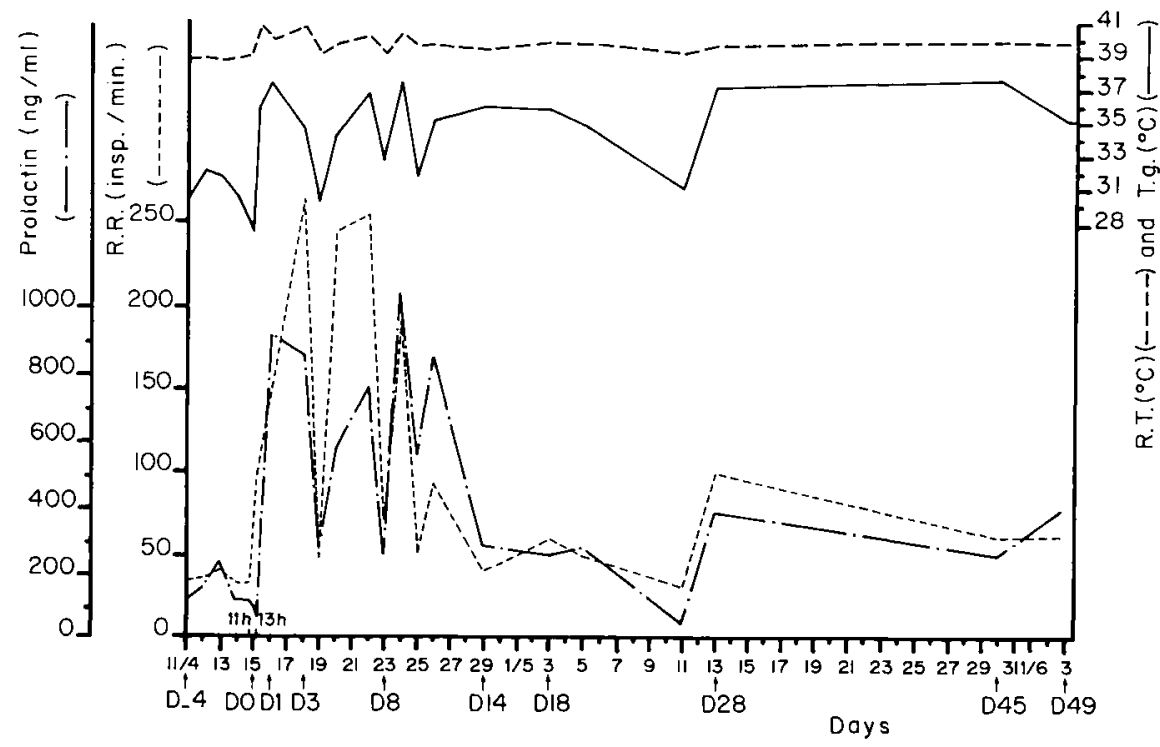

FIG. 2. - Profiles of thermophysiological (RR, RT) and hormonal (prolactin) parameters before and after solar exposure compared with variations in black-globe temperature $(\mathrm{Tg})$. Each point is the mean of $n=4$ animals. All measurements were carried out at the hottest hours of the day, i.e. 12.00 noon.

Cortisol decreased up to D8 and recovered the level recorded in shaded animals $(4.06 \pm 0.51$ and $4.63 \pm 0.79 \mathrm{ng} / \mathrm{ml})$.

Haematocrit decreased significantly $(28.62 \pm 0.51$ vs $32.99 \pm 2.29 \%$; $\mathrm{P}<0.05$ ) on D1, i.e. after a time-lag of $24 \mathrm{~h}$, then increased gradually between D11 and D18, reaching a value of $32.12 \pm 2.39 \%$ on D66.

\section{5) Models}

Respiratory rhythm (fig. 3a). - The Tg-linear asymptotic equation calculated from the data obtained from D18 after solar exposure was RR (inspirations/min) $=7.14 \mathrm{Tg}-192$ ( $\mathrm{n}=7 ; \mathrm{R}^{2}=0.66$ ).

The complete model was :

$R R=28.5+7.14(\mathrm{Tg}-30.8)\left(1+8.67 \exp \left(-(\operatorname{Lnt}-1.22)^{2} / 0.73\right)\right)$.

This accounts for $R^{2}=96 \%$ of the total variance. The values of $T_{\max }$ (corresponding to a maximal $\mathrm{RR}$ at a given $\mathrm{Tg}$ ) and relaxation time (time for which $\left.\left(R R-R R_{\infty}\right) /\left(R R_{\max }-R R_{\infty}\right) \leq 0.05\right)$ occurred 3.4 and 15 days, respectively, after insolation. Figure $3 a$ shows that the model and experimental data are in good agreement.

Prolactinemia. - Due to a longer relaxation time, the asymptotic equation, calculated with only 5 points (from D26), was :

$\mathrm{PRL}_{\infty}(\mathrm{ng} / \mathrm{ml})=40.7 \mathrm{Tg}-1185\left(\mathrm{n}=5 ; \mathrm{R}^{2}=0.67\right)$.

The complete model was :

PRL (ng/ml) $=1.4+40.7(\mathrm{Tg}-29.2)\left(1+2.75 \exp \left(-(\operatorname{Lnt}-1.03)^{2} / 2.10\right)\right)$. 


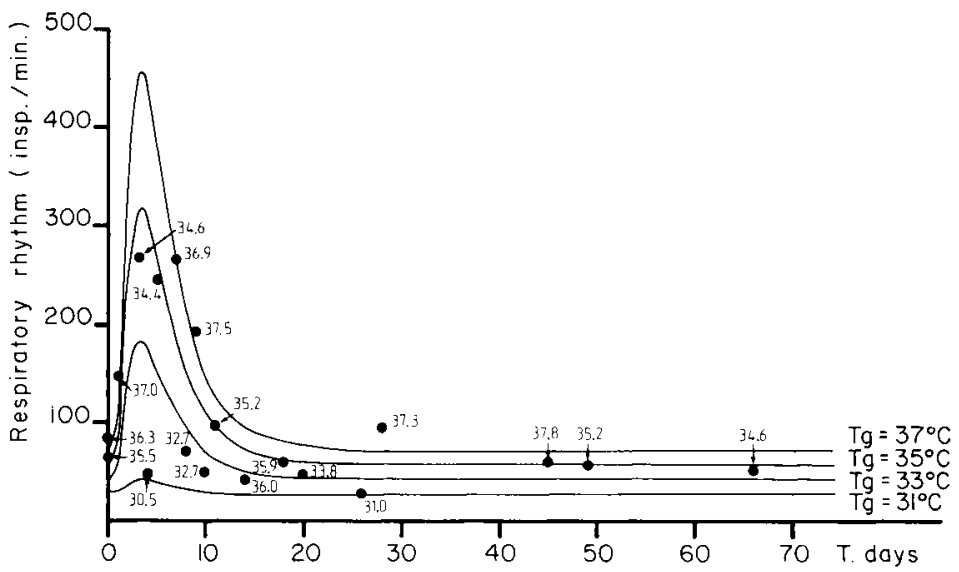

FIG. 3a. - Model, log-normal on time ( $\mathrm{t}$ ) and linear on black-globe temperature (Tg), of respiratory rhythm (RR) $\left(R^{2}=0.96\right)$. Experimental $\mathrm{Tg}$ values are given beside the experimental plots; theoretical $\mathrm{Tg}$ values are shown beside the curves.

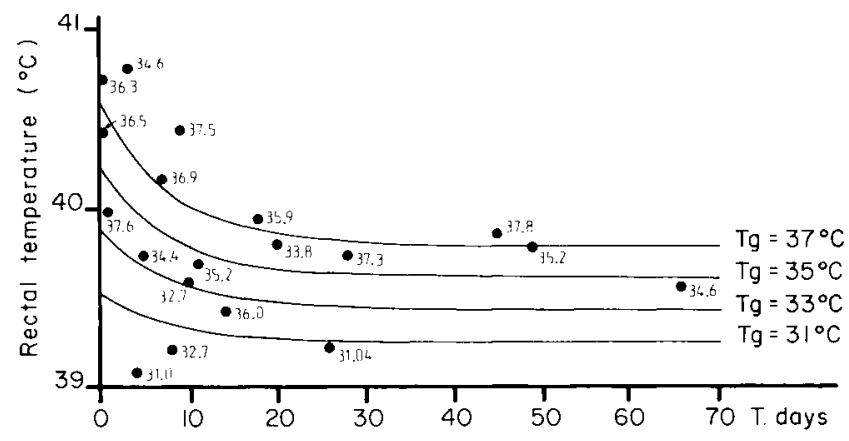

FIG. 3b. - The exponential model of rectal temperature (RT) decreases with time $(\mathrm{t})$ and is linear with black-globe temperature $(\mathrm{Tg})\left(R^{2}=0.59\right)$. Experimental $\mathrm{Tg}$ values are given beside the experimental plots; theoretical $\mathrm{Tg}$ values are shown beside the curves.

The adjustment, though less satisfactory than for RR, was fairly good $\left(R^{2}=0.75\right) . R^{2}$ decrease might be due either to the higher variability of prolactinemia or to less precise model simulation of the actual facts (see discussion).

As definied above, the values of $T_{\max }$ and relaxation time were 2.8 and 35 days, respectively. Theoretically, the asymptotic value of PRL should be calculated on only 3 points (after 35 days). However, on D25, the value of $X-X_{\infty}$ represented only $10 \%$ of the maximum and calculation on 5 points did not lead to a large error.

Rectal temperature (fig. 3b). - The asymptotic equation was : $R T_{\infty}=0.09032 \mathrm{Tg}+36.45\left(n=5 ; \mathrm{R}^{2}=0.88\right)$.

The global model was :

$\mathrm{RT}=38.98+0.09032(\mathrm{Tg}-28.01)(1+1.007 \exp (-\mathrm{t} / 8.048))$. 
This model accounted for only $59 \%$ of the variance; figure $3 \mathrm{~b}$ shows that the adjustment was not very good. Maximal rectal temperature was reached as soon as the animals were exposed to the sun. The relaxation time calculated as previously was 24 days.

\section{Discussion.}

Sudden and prolonged exposure to solar radiation was found to have a marked effect on the respiratory rhythm, rectal temperature and prolactinemia of male Creole goats (fig. 2); these criteria increased together with $T d, T w$, and mainly $\mathrm{Tg}$.

Hyperprolactinemia has already been reported in cattle (Wetteman and Tucker, 1974, 1976 ; Hooley et al., 1979 ; Schams et al., 1980 ; Roman-Ponce et al., 1981 ; Tucker and Petitclerc, 1982 ; Berbigier et al., 1984), sheep (Schillo et al., 1978) ; Bocquier (personal communication) and goats (Chemineau and Ravault, 1984 ; Sergent et al., 1984 ; Sergent, 1985).

The hypothalamo-pituitary axis of bucks strictly habituated to shade 17 months of habituation) did not seem to be immediately activated by the stimulus of solar radiation since hyperprolactinemia was only detected after a time-lag of $24 \mathrm{~h}$, even though in goats permanently habituated outside plasma prolactin immediately follows variations in insolation (Chemineau and Ravault, 1984 ; Sergent et al., 1984). Moreover, in our experimental conditions (fig. 1), the hourly pattern of circulating prolactin on DO was not disturbed by solar exposure and was not different from that observed at the same season in the similar bucks kept permanently in the shade (Sergent et al., 1985, in preparation).

One hypothesis is that the 24-hour time-lag might correspond to the time required for the prolactin secretory cells to become sensitive. The second hypothesis (which does not exclude the first one) is that a high plasma cortisol level at the moment of solar exposure (between 12.00 and 13.00) would prevent PRL response to solar stimulation (see Yelvington et al., 1984).

Rectal temperature increased immediately after insolation. This is in agreement with the rapid RT increase observed in animals subjected to heat stress in a climatic chamber (e.g. Halipre, 1973 ; Bouvier et al., 1974), i.e. in the beginning, the organism responds poorly to the sun since rectal temperature (heat storage) and respiratory rate (heat dissipation) rise simultaneously.

However, RT and RR began to increase before solar exposure (fig. 1, large arrow) due to the endogenous rhythm particular to homeotherms (inner temperature increase from 6.00 to 16.00 ). The maximal levels of these parameters are comparable whith the ones reached using an experimental sun-shade design in similar animals. In that experiment, we observed circadian variations in RT and RR in each " climatic " treatment, i.e. in shade between 11.00 and 12.00, the RT rose $+0.11^{\circ} \mathrm{C}$ (39.35 to 39.46$)$, $\mathrm{RR}$ remained at $\simeq 70 \mathrm{insp} / \mathrm{min}$ for $\mathrm{Ta} \simeq$ $30.35^{\circ} \mathrm{C}$ and $\mathrm{Tg}=32.6^{\circ} \mathrm{C}$. In sunlight, RT increased $+0.12^{\circ} \mathrm{C}$ (39.39 to 39.51) and $R R+15 \mathrm{insp} / \mathrm{min}$ (131 to 146$)$ for a Ta rise of $+0.30^{\circ} \mathrm{C}(31.15$ to 31.45$)$ and a $\mathrm{Tg}$ rise of $+0.15^{\circ} \mathrm{C}$ (36.85 to 37) (Sergent et al., 1985, in preparation). 
In the present experiment, RT rose $+1.28{ }^{\circ} \mathrm{C}(39.12$ at 11.00 in shade to 40.40 at 12.10 in the sun) and RR increased $+31 \mathrm{insp} / \mathrm{min}$ (33 to 64).

Therefore, the values of RT, RR (fig. 1) and PRL (fig. 2), obtained when the bucks were suddenly exposed to the sun, were several orders of magnitude greater than the values obtained during a normal circadian rhythm; these events are actually induced by sudden solar exposure.

The intensified respiratory rate (or panting) was probably a thermolytic emergency response to acute solar exposure ; however it was not fully developed at the beginning of heat stress.

The variation models of RR, PRL and RT, allowing us to better quantify the former observations, gave an order of magnitude of the combined effect of black globe temperature and time on these 3 variables by means of determination coefficients $\left(R^{2}=0.96,0.75\right.$ and 0.59 , respectively; $\mathrm{Tg}$ and $t$ accounted for $96 \%$ of the variance in respiratory rhythm). These models showed where the maxima of RR and PRL were located in time after insolation (3.4 and 2.8 days, respectively, corrected to 3-days considering measurement frequency) and permitted quantification of the times of return to equilibrium of the variables 115 , 35 and 24 days for RR, PRL and RT, respectively); adaptation to the new environment was complete after a maximum of one month. However, these models were chosen only on the basis of the curve shape of the 3 variables, according to black globe temperature and time, and because of some simple, easily verifiable hypotheses. Some results are apparently not valid: the model used for prolactinemia supposes an increase with $\mathrm{Tg}$ from Do ; in fact, prolactinemia did not react to $\mathrm{Tg}$ on the first day of sun exposure (see fig. 1), or at least it was doubtful. Taking into account the scattered RT values, it is not possible to say that the exponential model is better than any other curvilinear one. However, these models seem efficient, as shown by the high values of the determination coefficients.

During the first 3 days after solar exposure, the major part of the extra heat seemed to be eliminated by respiratory evaporation. Then, as this thermolytic route declined, sweating (skin transpiration) became the main thermolytic reaction, but we did not measure it. This observation may be related to the fact that serum potassium rate already tended to decrease $1 \mathrm{~h}$ after insolation. It has been well established that potassium is the main electrolyte eliminated in cattle during sweating (Macfarlane, 1976 ; El Nouty et al., 1980).

The last thermolytic mechanism might be a reduction of metabolism (decrease in heat production) accompanied by a slowing-down of the glucocortoid and thyroid functions. This could not be affirmed by our experiment on the basis of only the cortisolemia since cortisolemia recovered its initial level (shade) after 8 days of insolation. Moreover, the average daily body gain after heat exposure was not significantly different from that recorded during the last two months in shade $(15.05 \pm 10 \mathrm{vs} 7.71 \pm 4.5 \mathrm{~g})$. Cortisol, generally considered as a catabolic hormone (Thomas and Rodway, 1983) and negatively correlated with growth in cattle (Purchas et al., 1971), did not seem to be involved here. This is in agreement with our previous results, i.e. the plasma 
cortisol level was not significantly different whether the animals were kept permanently under a shelter or outside (Sergent et al., 1984).

Variations in plasma prolactin levels are associated with temperature variations, especially under direct natural insolation. Prolactin reactivity does not seem to be a general (aspecific) stress response but is specific to solar radiation, at least above a $\mathrm{Tg}$ threshold of $32{ }^{\circ} \mathrm{C}$. In addition, significant correlations between RT and PRL show that PRL secretion could be involved in thermoregulation.

These results and the thermoregulation failure observed in animals treated with an inhibitor of prolactin secretion at the hottest hours of the day (Berbigier, Sergent, and Ravault, 1985) support the putative role of prolactin in caprine thermoregulation. However, other experiments must be carried out to demonstrate a perfect causal relationship between prolactin and thermoregulation.

\section{Conclusion.}

When male Creole goats, previously acclimatized to shade, were suddenly exposed to the sun over a period of time in natural conditions, the following observations were made :

1) plasma cortisol level rose immediately but returned to shade values after one week ;

2) rectal temperature rose immediately then decreased and stabilized at its initial level about 3 weeks later ;

3) blood potassium rate tended to decrease $1 \mathrm{~h}$ after insolation, but the blood sodium rate remained steady ;

4) haematocrit decreased on D1 (24 h after solar exposure began), but returned to initial level after 3 weeks ;

5) respiratory rhythm increased gradually but returned to shade equilibrium about 2 weeks later ;

6) there was no specific solar-exposure increase in PRL on DO; PRL rose dramatically on D1 and stabilized after about 3 weeks at a significantly higher level than the shade level:

7) $R R$ and $P R L$ decreased Log-normally on time (t) and linearly on black-globe temperature $(\mathrm{Tg})$, while RT decreased exponentially with $\mathrm{t}$ and linearly with $\mathrm{Tg}$; 8 ) body weight gain was not affected.

It is concluded that habituation to direct solar radiation produces high plasma prolactin levels and that, even in tropical genotypes, thermolytic mechanisms are not immediately available, i.e. an adaptation period of about 3 weeks is required. 
Acknowledgements. - The authors are grateful to S.A. Sophie and P. Vinglassalon for their help in manipulating the animals, to Chantal Meusnier and Nicole Vermeire for technical collaboration, to Annick Bourroche for her help in the English translation, to Michelle Huc for typing the paper and to Joël Gallé for the illustrations.

Résumé. Effet d'une insolation brutale sur les paramètres thermophysiologiques, la cortisolémie et la prolactinémie de boucs Créoles.

La température rectale (TR), le rythme respiratoire (RR), les concentrations plasmatiques de cortisol et de prolactine (PRL) et l'hématocrite sont mesurés à midi chez des boucs lors de leur accoutumance à l'ombre, au cours de leur exposition soudaine au soleil, puis lors de leur maintien en plein air. Simultanément sont relevées les données microclimatiques notamment la température de la boule noire (Tb).

Le jour de la mise au soleil (Jo), l'augmentation de TR et de RR caractéristique du rythme circadien est amplifiée sitôt l'exposition (TR : $40,84 \pm 0,23{ }^{\circ} \mathrm{C}$ vs $39,48 \pm 0,19{ }^{\circ} \mathrm{C}$, $\mathrm{P}<0,001$; RR : $98 \pm 22$ vs $35 \pm 3 \mathrm{resp} / \mathrm{mn}, \mathrm{P}<0,01)$. Le cortisol plasmatique augmente aussi $(17,7 \pm 8,6$ vs $5,57 \pm 1,7 \mathrm{ng} / \mathrm{ml}, \mathrm{P}<0,05)$. Au bout de $24 \mathrm{~h}\left(\mathrm{~J}_{1}\right)$, la concentration plasmatique de prolactine augmente démesurément $(923 \pm 653$ vs $90 \pm 22 \mathrm{ng} / \mathrm{ml}, \mathrm{P}<0,05)$ et l'hématocrite décroît $(28,6 \pm 2,3$ vs $33 \pm 2,3 \%, P<0,05)$.

Pour rendre compte des effets simultanés du temps $(t)$ et de $\mathrm{Tb}$, sont développés un modèle Log-normal en fonction du temps et linéaire en fonction de Tb pour RR et PRL, ainsi qu'un modèle exponentiel décroissant en fonction de $t$ et linéaire en fonction de $\mathrm{Tb}$ pour TR : les coefficients de détermination sont respectivement $R^{2}=0.96,0.75$ et 0.59 .

Environ 3 semaines plus tard (" période d'adaptation ») TR, RR et la PRL plasmatique se stabilisent : TR et RR retrouvent leurs valeurs à l'ombre, tandis que la PRL se maintient à un niveau supérieur à celui qu'elle avait à l'ombre $(248 \pm 109$ vs $130 \pm 50 \mathrm{ng} / \mathrm{ml}$, $P<0,05)$.

Le délai de $24 \mathrm{~h}$ dans le déclenchement de l'hypersécrétion prolactinique et le rôle de la prolactine dans la thermorégulation sont discutés.

\section{References}

BACHACOU J., MASSON J. P., MILLIER C., 1981 AMANCE 81, Manuel de la programmatheque scientifique, INRA, Versailles, $516 \mathrm{p}$.

BERBIGIER P., 1982. Analyse physique des pertes thermiques de l'animal vers son environnement. Influence des facteurs climatiques. In Actions du climat sur l'animal au pâturage, Theix, 31 mars-10r avril 1982. - Ed. INRA Publ., 1982.

BERBIGIER P., SERGENT D., RAVAULT J. P., 1984. Effect of inhibition of prolactin secretion on rectal temperature, respiratory rhythm, water and dry matter intake of the Creole male dwarf goat in Guadeloupe (FWI) (submitted to publication).

BERBIGIER P., SERGENT D., GAUTHIER D., CHEMINEAU P., HEYMAN Y., 1984. Effet du climat tropical sur les bovins et les caprins de Guadeloupe (Antilles Françaises). Conséquences pour les bâtiments d'élevage. 10e Congr. inter. du Génie Rural, Budapest. 3-7 Sept. 1984.

BIANCA W., 1965. Cattle in a hot environment. J. Dairy Res., 32, 291-345.

BOCQUIER F. (personnal communication). 
BOSC M., FEVRE J., 1977. Evolution de la cortisolémie au cours de la première semaine de la vie, chez le veau (Bos taurus) et chez l'agneau (Ovis aries). C.R. Acad. Sc., Paris, 284, sér. D., 2373-2376.

BOUVIER J. C., ESPINOSA-MOLINER J., VERMOREL M., 1974. Intluence de temperatures et d'hygrométries élevées pendant une partie de la journée sur la thermorégulation du veau pré ruminant à l'engrais. Ann. Biol. anim. Bioch. Biophys., 14, 721-727.

CHEMINEAU P., RAVAULT J. P., 1984. Variations horaires de la température rectale et de la prolactinémie chez le Cabrit Créole maintenu à l'extérieur en milieu tropical. Reprod. Nutr. Dévelop., 24, 71-80.

EL NOUTY F. D., ELBANNA I. M., DAVIS T.P., JOHNSON H. D., 1980. Aldosterone and ADH response to heat and dehydration in cattle. J. appl. Physiol., 48, 249-255.

HALIPRE A., 1973. Etude du caractère culard. X. Sensibilité des bovins culards au stress thermique. Ann. Génét. Sél. anim., 5, 441-449.

HOOLEY R. D., FINDLAY J. K., STEPHENSON R.G.A., 1979. Effect of heat stress on plasma concentrations of prolactin and luteinizing hormone in ewes, Aust. J. biol. Sci., 32, 231-235.

KANN G., 1971. Dosage radioimmunologique de la prolactine plasmatique chez les ovins. C.R. Acad. Sci. Paris, Sér. D, 272, 1808-1811.

LADELL W. S. S., 1964. Terrestrial animals in humid heat. Man, 625-659. In D.B. DILL, Handbook of physiology, Sect. 4, Adaptation to the environment. Amer. Physiol. Soc., Washington D.C.

MACFARLANE W. V., 1968. Adaptation of ruminants to tropics and deserts. Philadelphia, PA, Lea Febiger, 164-182.

MURPHY B. E. P., 1967. Some studies of the protein-binding of steroids and their application to the routine micro and ultramicromeasurement of various steroids in body fluids by competitive protein binding radioassay. J. clin. Endocr. Metab., 27, 973-977.

PURCHAS R. W., PEARSON A. M., HAFS H.D., TUCKER H. A., 1971. Some endocrine influences on the growth and carcass quality of Holstein heifers. J. anim. Sci, 33, 836-842.

ROMAN-PONCE H., THATCHER W. W. WILCOX C.J., 1981. Hormonal interrelationships and physiological responses of lactating dairy cows to a shade management system in a subtropical environment Theriogenology, 16, 139-154.

SCHAMS D., STEPHAN E., HOOLEY R.D., 1980. The effect of heat exposure on blood serum levels of anterior pituitary hormones in calves, heifers and bulls. Acta endocr., 94, 309-314.

SCHILLO K. K., ALLISTON C.W., MALVEN P. V., 1978. Plasma concentrations of luteinizing hormone and prolactin in ovariectomized ewe during induced hyperthermia. Biol. Reprod., 19, 306-313.

SERGENT D., 1985. Conséquences thermophysiologiques et endocriniennes de l'exposition au soleil chez le bouc créle de Guadeloupe. Th. Doct. $3^{3}$ cycle. Univer. P. et M. Curie. Paris VI.

SERGENT D., GAUTHIER D., CHEMINEAU P., 1984. Conséquences endocriniennes de l'exposition au soleil chez les caprins et bovins Créoles de Guadeloupe, 199-212. In Congr. int. Reproduction des ruminants en zone tropicale. Pointe-à-Pitre (FWI), 8-10 juin 1983. INRA Publ., $n^{\circ} 20$.

SERGENT D., KANN G., BERBIGIER P., 1985. (in preparation).

THOMAS K. M., RODWAY R.G., 1983. Effects of trenbolone acetate on adrenal function and hepatic enzyme activities in female rats. J. Endocr., 98, 121-127.

TUCKER H. A., PETITCLERC D., 1982. The role of the eye on secretion of prolactin during various photoperiods and seasons in cattle, 147-156. In : R. ORTAVANT, J. PELLETIER, J. P. RAVAULT, Photoperiodism and reproduction in vertebrates. In Coll. Nouzilly (Fr) 24-25 sept. 1981.

WETTEMAN R. P., TUCKER H. A., 1974. Relationship of ambient temperature to serum prolactin in heifers. Proc. Soc. exp. Biol. Med., 146, 908-911.

WETTEMAN R. P., TUCKER H. A., 1976. The influence of low and elevated ambient temperatures on serum prolactin and growth hormone in heifers. A review. Int. J. Biometeor., 20, 36-41.

YELVINGTON D. B., WEISS G. K., RATNER A., 1984. Effect of corticosterone on the prolactin response to psychological and physical stress in rats. Life Sci., 35 1705-1711. 